\title{
Defining criteria to select reference sites in Mediterranean streams
}

\author{
M. M. Sánchez-Montoya • M. R. Vidal-Abarca • \\ T. Puntí · J. M. Poquet · N. Prat · M. Rieradevall · \\ J. Alba-Tercedor · C. Zamora-Muñoz • M. Toro • \\ S. Robles · M. Álvarez · M. L. Suárez
}

Received: 22 October 2007 /Revised: 23 July 2008/Accepted: 24 August 2008/Published online: 30 September 2008

(C) Springer Science+Business Media B.V. 2008

\begin{abstract}
The European Water Framework Directive establishes the need to define stream type-specific reference conditions to identify "high ecological status". Methods for selecting reference sites using a priori criteria have been proposed by many authors. A review of these criteria revealed that the most relevant criteria for streams and rivers were those related to riparian vegetation, diffuse and point sources
\end{abstract}

Handling editor: R. Bailey

M. M. Sánchez-Montoya ( $₫)$ · M. R. Vidal-Abarca .

M. L. Suárez

Department of Ecology and Hydrology,

University of Murcia, Espinardo, 30100 Murcia, Spain

e-mail: marsanch@um.es

T. Puntí $\cdot$ N. Prat · M. Rieradevall

Department of Ecology, University of Barcelona,

08028 Barcelona, Spain

J. M. Poquet · J. Alba-Tercedor · C. Zamora-Muñoz Department of Animal Biology, University of Granada, 18071 Granada, Spain

M. Toro

Division of Ecology of Continental Aquatic Systems, CEDEX, 28005 Madrid, Spain

S. Robles

Cimera Estudios Aplicados SL, Parque Científico de

Madrid, 28760 Madrid, Spain

M. Álvarez

Area of Ecology, University of Vigo, 36200 Vigo, Spain of pollution, river morphology and hydrological conditions and regulation. In this work, we propose 20 criteria that reflect the characteristics of Mediterranean streams and their most frequent disturbances for the selection of reference sites in Mediterranean streams in Spain. We studied 162 sites located in 33 Mediterranean basins belonging to five stream types. Of the locations, $57 \%$ were selected as a priori reference sites by having applied the proposed criteria. Reference sites were identified for all stream types except for "large watercourses" which includes the lower reaches of some rivers in this study area. This a priori selection of reference sites was subjected to validation using the macroinvertebrate community by applying of an IBMWP threshold, which is considered to be an indicator of undisturbed sites in Mediterranean streams. This approach determined that whole of this selection $(100 \%)$ could be considered valid reference sites. Furthermore, we identified differences in the reference conditions for each stream type on the basis of macroinvertebrate assemblage composition.

Keywords Bioassessment - Reference conditions · Mediterranean streams · Water Framework Directive $\cdot$ Ecological status - GUADALMED project

\section{Introduction}

An important element of the biological assessment of stream conditions is an assessment of the direct or 
indirect effects of human activities or disturbances. Most biological assessments are based directly or indirectly on the concept of comparing the current condition to natural conditions (structure, composition, function, diversity) in the absence of human disturbance or alterations (Stoddard et al., 2006). The Reference Condition Approach (RCA; Reynoldson et al., 1997; Bailey et al., 1998; Reynoldson \& Wright, 2000; Bailey et al., 2004) has been also defined under this Reference Condition (RC) concept, defined as the condition in the absence of human disturbance which is used to describe the standard, or benchmark, against which the current condition is compared. Hence, the RCA depends on the identification and sampling of reference sites and the result is a database with the biological and environmental attributes that represent this RC (Bailey et al., 2004).

This concept has been adopted by the Water Framework Directive (WFD-European Commission, 2000) since it requires the ecological status assessment, which may be expressed as a deviation from the near-natural reference condition. According to the WFD, the RC should be linked to stream typology and reference sites should present the full range of conditions expected to occur naturally within a given stream type (e.g. Barbour et al., 1996, 2004; Reynoldson \& Wright, 2000; Stoddard et al., 2006). The bases for the characterisation of river typology and the identification of the $\mathrm{RC}$ for each stream type are provided in Annexe II of the Directive.

Before the WFD, water quality monitoring programmes in most EU Member States were mainly based on chemical and physical variables. Only around half the programmes included biological parameters in their assessment and classification of river quality (Hering et al., 2003). Nowadays, in the WFD context, the ecological status of rivers must be determined by biological quality elements (phytobenthos, macrophytes, macroinvertebrates and fishes) and has to be supported by hydro-morphological and physico-chemical quality elements (European Commission, 2000).

Many authors have defined the term RC (e.g. Davies, 1994; Hughes, 1995; Reynoldson et al., 1997; Chovarec et al., 2000; Bailey et al., 2004; Stoddard et al., 2006), and all of them emphasise that this condition corresponds to a state of very low environmental pressure or degradation. Although several methods have been proposed to establish the RC (extensive spatial survey, predictive modelling, historical data, paleo-reconstruction and expert judgment), the extensive spatial surveys are one of the most widely used approaches in rivers and streams (e.g. Wallin et al., 2003). The use of this method implies that a sufficient number of undisturbed or minimally disturbed sites are available in a specific stream type to establish the RC by statistic measures such as median values or arithmetic means. Regardless of the method followed by the EU Member States, the WFD requires the approaches being applied to provide a high level of confidence.

The recognition and selection of reference sites is a critical step in the design of extensive spatial surveys in establishing the RC (Reynoldson \& Wright, 2000; Bailey et al., 2004) because these sites are the baseline for comparing test sites (e.g. Reynoldson et al., 1997; Norris \& Thoms, 1999; Bailey et al., 2004). This selection of reference sites is commonly founded on a priori established criteria (Barbour et al., 1996; Reynoldson et al., 1997; Stoddard et al., 2006) based on different pressures derived from human activities that may affect the ecological status and which distinguish a reference site from a pressure-exposed site (Hering et al., 2003). Reference sites must fulfil specific operational criteria that easily indicate the absence of exposure stressors (Bailey et al., 2004). The factors chosen to be included in the a priori criteria attempt to define the least amount of environmental disturbance caused by human activities (Stoddard et al., 2006). Therefore when establishing criteria, the goal is to explicitly define the reference or acceptable healthy ecosystem (Bailey et al., 2004).

After this a priori selection, site validation must be applied to confirm and refine the selection of reference sites (Barbour et al., 1996) since some kind of disturbances are difficult to detect with the common screening methods used (Hering et al., 2003; Nijboer et al., 2004). The validation of a preliminary selection of reference sites can be specially needed in European rivers because they have been affected by multiple pressures such as organic pollution and flow regulation, among others (Hering et al., 2003). Therefore, establishing the $\mathrm{RC}$ by the selection method of reference sites in European rivers is expected to be problematic (Bonada et al., 2004; Nijboer et al., 2004), particularly in lowland rivers with a long history of intense flow regulation, agricultural development and pollution (Petts, 1989). 
The GUADALMED Project focuses on the development of tools to facilitate the establishment of the RC in Mediterranean streams in Spain (Prat 2004). During the first phase of the project, the results showed that the use of a priori criteria was a better tool for the selection of reference sites than expert judgment because subjectivity was implicit in the experts' interpretation of the "minimally disturbed site" concept (see Bonada et al., 2004). The main aim of the second phase was to define clear and operational criteria adapted to the particularities of Mediterranean, based on the criteria defined by Sánchez-Montoya et al. (2005), which allow the selection of validated reference sites in different Mediterranean stream types.

The specific objectives of this study were:

1. To review commonly used criteria to select reference sites in different regions.

2. To propose clear and operational criteria to select reference sites in Mediterranean streams in Spain (Mediterranean reference criteria, MRC).

3. To evaluate the selection of reference sites according to the MRC by comparing the values of four macroinvertebrate metrics between reference and disturbed sites for distinct stream types.

4. To corroborate the reference site selection by applying validation criteria.

\section{Materials and methods}

Study area and sampling sites

This study was performed in 33 basins located on a latitudinal, thermal and pluviometric gradient along the eastern coast of Spain and the Balearic Islands (Fig. 1). Basins vary in area and discharge regime, among others features. They are all influenced by the Mediterranean climate with significant spring and autumn rainfall (Köppen, 1923). Hence, all the rivers sampled show high variability in annual discharge, with frequent floods and droughts (Gasith \& Resh, 1999). More information about the studied basins can be found in Sánchez-Montoya et al. (2007).

We examined 162 potential reference sites defined as "least disturbed", following the criteria defined by

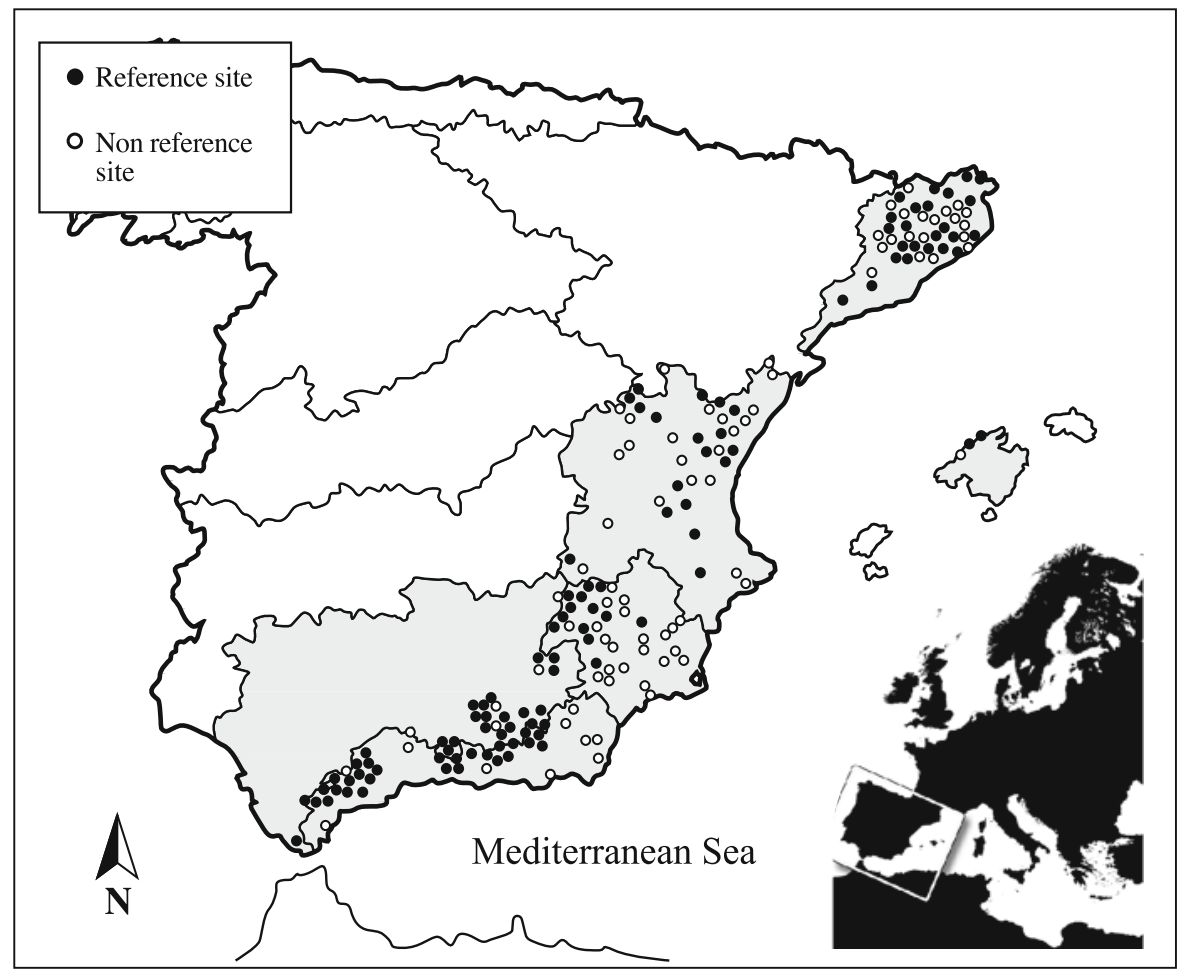

Fig. 1 Distribution of the 162 sampling sites. Reference and non reference sites according to the final selection process 
Bonada et al. (2004). These sites belong to perennial or temporary streams, which are classified into five different stream types: temporary streams, evaporite calcareous streams at medium altitude, siliceous headwaters streams at high altitude, calcareous headwaters streams at medium to high altitude and large watercourses (see Sánchez-Montoya et al., 2007). Table 1 shows the main characteristics of these five stream types. The 162 studied sites are distributed along the main rivers and their tributaries (Fig. 1).

\section{Revision of reference criteria}

Many criteria used to select the reference sites in various regions were compiled to not only analyse which were the most frequently used, but to determine the most appropriate criteria for Mediterranean streams. The criteria analysed were those defined by Davies (1994) in Australia, and Hughes (1995) and Barbour et al. (1996) in the United States. We also examined the criteria proposed more recently by Ehlert et al. (2002), Hering et al. (2003), Wallin et al. (2003), Bonada et al. (2004) and Nijboer et al. (2004) for European rivers for the selection of reference sites equivalent to "high status" in the context of WFD.

\section{Selection of reference sites}

After carefully reviewing the criteria used by aforementioned authors, 20 criteria were defined to be representative of Mediterranean conditions (Mediterranean Reference Criteria-MRC). More details about the selected criteria are provided in the Results and Discussion sections of this article.
To calculate the percentage of different land uses, firstly a digital terrain model (DTM $30 \times 30 \mathrm{~m}$; Centro Geográfico del Ejército, Ministerio de Defensa, Spain, 2005) and the Arc/Info software (version 9.0, ESRI, Redlands, California, USA, 2005) were used to delimit and calculate the water drainage area as a new polygon for all the sampling sites. Secondly, the percentages of intensive and extensive agriculture, urban zones, burnt area and natural land use were calculated by intersecting the Corine Land Cover 2000 Programme (Spain, Scale 1:100.000, Instituto Geográfico Nacional, Centro Nacional de Información Geográfica) with the water drainage area. Information on the remaining criteria was obtained from maps and available data, some of which were from the water agencies of each river basin district. This information was checked during a preliminary site inspection.

The 162 sites were classified into three "exposure to stressors" levels on the basis of the level of disturbance (1-3). These levels were determined by the number of MRC criteria fulfilled by each site. Only those that satisfied all 20 criteria were considered reference sites, which were termed undisturbed sites or very minor disturbed sites (exposure to stressors level 1). The rest which fulfilled fewer criteria were classified as disturbed sites with two degrees of degradation. If sites fulfilled from 16 to 19 criteria, they were considered minor disturbed sites (exposure to stressors level 2). Finally, sites were considered to be disturbed sites when they fulfilled fewer than 16 of the 20 criteria (exposure to stressors level 3).

To assess the aforementioned classification of sampling sites, according to the number of criteria

Table 1 Average and SD (in parenthesis) values of main environmental variables which characterised the five stream types established in the study area by Sánchez-Montoya et al. (2007)

\begin{tabular}{|c|c|c|c|c|c|}
\hline $\begin{array}{l}\text { Code stream } \\
\text { type }\end{array}$ & Definition & Hydrologic state & Stream order & $\begin{array}{l}\text { Surface drainage } \\
\text { area }\left(\mathrm{km}^{2}\right)\end{array}$ & Altitude (m) \\
\hline $\mathrm{T} 1$ & Temporary streams & Intermittent/Ephemeral & $1.1( \pm 0.3)$ & $22( \pm 35)$ & $645( \pm 523)$ \\
\hline $\mathrm{T} 2$ & $\begin{array}{l}\text { Evaporite calcareous at medium } \\
\text { altitude streams }\end{array}$ & Perennial seasonal & $1.9( \pm 0.8)$ & $200( \pm 290)$ & $541( \pm 188)$ \\
\hline T3 & $\begin{array}{l}\text { Siliceous headwaters at high } \\
\text { altitude streams }\end{array}$ & Perennial seasonal & $1.3( \pm 0.6)$ & $47( \pm 118)$ & $720( \pm 225)$ \\
\hline T4 & $\begin{array}{l}\text { Calcareous headwaters at medium } \\
\text { and high altitude streams }\end{array}$ & Perennial seasonal & $1.7( \pm 0.9)$ & $149( \pm 38)$ & $689( \pm 192)$ \\
\hline T5 & Large watercourse & Perennial seasonal & $4.3( \pm 0.7)$ & $3490( \pm 1675)$ & $239( \pm 187)$ \\
\hline
\end{tabular}


fulfilled, values of four macroinvertebrate metrics were calculated and compared at each exposure to stressors level for the five stream types. For this purpose, the 162 sites were sampled in the spring, summer and autumn of 2003. A total of 469 macroinvertebrate samples were taken. Sites belonging to stream type 1 (temporary streams) were not sampled on each occasion because they were dry in at least one season, most frequently in summer. A multihabitat semiquantitative kick-sample, as described by Zamora-Muñoz \& Alba-Tercedor (1996), was taken on each sampling occasion using the protocol described by Jáimez-Cuéllar et al. (2004). Macroinvertebrate samples were collected from all habitats, incorporating riffles, runs and pool if these habitats were present in the stream stretch in question, with a kick-net $(250-400 \mu \mathrm{m})$, and they were preserved in $100 \%$ ethanol. Effort was allocated in proportion to the occurrence of each habitat. Samples were examined under a stereoscope in the laboratory and at least 200 individuals in each sample were randomly picked and identified at the family level, except for Ostracoda, Oligochaeta and Hydracarina. Large uncommon individuals were picked individually, as described in Barbour et al. (1999).

The Iberian Biomonitoring Working Party Biotic Index (IBMWP; Alba-Tercedor \& Sánchez-Ortega 1988; Alba-Tercedor et al., 2004) and the IASPT (Iberian Average Score per Taxon) were applied as biotic integrity indices and the total number of families (NFAM) and the number of EPT taxa (number of families belonging to Ephemeroptera, Plecoptera and Trichoptera) were applied as single metrics. The mean values of macroinvertebrate metrics and indices of the three sampling occasions were used to perform multiple box-plots to represent the range of variation of each metric within the three exposures to stressors levels for the five stream types considered.

\section{Validation of reference sites and final selection}

In order to refine and confirm the a priori selection of reference sites by applying of the MRC, a validation process was applied. The validation method must be preferably an approach which does not depend on the method used to select the reference sites (Nijboer et al., 2004). Macroinvertebrate community data were selected as indicators of biological conditions to corroborate whether a priori reference sites presented undisturbed or near-natural conditions. Biological threshold defined by several authors as a validation criterion of undisturbed sites in Mediterranean streams to confirm that near natural conditions was used. This threshold was the value of the IBMWP $>100$ established by Alba-Tercedor \& Sánchez-Ortega (1988) as a high quality class indicator. This validation criterion was also applied to Mediterranean streams in Portugal by Chaves et al. (2006). This index was designed mainly to detect organic pollution in permanent streams and therefore this threshold can not be applied for temporary streams where, additionally, large differences in macroinvertebrate assemblages were observed as a result of variability in salinity and hydrology (Sánchez-Montoya et al. 2007). A priori reference sites had to fulfil the biological validation criterion in the three sampling occasions (spring, summer and autumn) to be considered as a reference site in the final selection.

\section{Results}

Review of the criteria used to select reference sites

To facilitate further analysis, all the criteria were grouped into three general groups of attributes: (a) biological (Table 2), (b) physical and chemical (Table 3) and (c) hydro-morphological (Table 4). Furthermore, these groups were arranged into 12 categories following some authors' classifications. These categories were: riparian vegetation and floodplain, introduced species, fisheries and aquaculture, biomanipulation, wildlife, catchment vegetation, macroinvertebrate community, point source pollution, diffuse source pollution and land use, channel morphology, habitat composition, hydrologic conditions and regulation.

Proposal of criteria for Mediterranean streams in Spain (Mediterranean reference criteria, MRC)

On the basis of the reference criteria used by other authors and considering the particular conditions of Mediterranean streams, we proposed 20 criteria that a site has to fulfil to be considered a reference site (Table 5). The spatial scale of application was 
Table 2 Criteria related to biological attributes applied to select reference sites in previous studies

\begin{tabular}{|c|c|c|}
\hline Biological criteria & Definition & Reference \\
\hline \multirow{9}{*}{$\begin{array}{l}\text { Riparian vegetation and } \\
\text { floodplain }\end{array}$} & Lateral connectivity between riparian vegetation and floodplain & Hering et al. (2003) \\
\hline & Presence of natural floodplain vegetation & $\begin{array}{l}\text { Ehlert et al. (2002), Nijboer } \\
\text { et al. (2004) }\end{array}$ \\
\hline & Floodplain not cultivated & $\begin{array}{l}\text { Hering et al. (2003), Nijboer } \\
\text { et al. (2004) }\end{array}$ \\
\hline & Riparian vegetation extensive and old & $\begin{array}{l}\text { Hughes (1995), Barbour et al. } \\
\text { (1996) }\end{array}$ \\
\hline & Riparian structure complex & Hughes (1995) \\
\hline & $\begin{array}{l}\text { Having adjacent natural vegetation appropriate to the type and } \\
\text { geographical location of the river }\end{array}$ & $\begin{array}{l}\text { Barbour et al. (1996), Wallin } \\
\text { et al. (2003) }\end{array}$ \\
\hline & Natural cover or riparian zone & Bonada et al. (2004) \\
\hline & Native species in riparian zone & Bonada et al. (2004) \\
\hline & No impacts in riparian zone & Bonada et al. (2004) \\
\hline \multirow[t]{3}{*}{ Introduced species } & No introduced species & Nijboer et al. (2004) \\
\hline & $\begin{array}{l}\text { Introductions compatible with very minor impairment of the } \\
\text { indigenous biota by introduction of fish, crustacean, mussels or } \\
\text { any other kind of plants and animals }\end{array}$ & $\begin{array}{l}\text { Hering et al. (2003), Wallin } \\
\text { et al. (2003) }\end{array}$ \\
\hline & No impairment by invasive plant or animal species & $\begin{array}{l}\text { Hering et al. (2003), Wallin } \\
\text { et al. (2003) }\end{array}$ \\
\hline \multirow[t]{3}{*}{$\begin{array}{l}\text { Fisheries and } \\
\text { aquaculture }\end{array}$} & $\begin{array}{l}\text { Fishing operations should allow for the maintenance of the } \\
\text { structure, productivity, function and diversity of the ecosystem } \\
\text { (including habitat and associated dependent and ecologically } \\
\text { related species) on which the fishery depends }\end{array}$ & Wallin et al. (2003) \\
\hline & $\begin{array}{l}\text { Stocking of non indigenous fish should not significantly affect the } \\
\text { structure and functioning of the ecosystem }\end{array}$ & Wallin et al. (2003) \\
\hline & No impact from fish farming & $\begin{array}{l}\text { Hering et al. (2003), Wallin } \\
\text { et al. (2003) }\end{array}$ \\
\hline Biomanipulation & No biomanipulation & Wallin et al. (2003) \\
\hline \multirow[t]{2}{*}{ Wildlife } & Wildlife and benthos evident & Hughes (1995) \\
\hline & $\begin{array}{l}\text { Presence of animals, such as piscivorous birds, mammals, } \\
\text { amphibians, and reptiles, that are representative of the region } \\
\text { and derive some support from aquatic ecosystems }\end{array}$ & Barbour et al. (1996) \\
\hline Catchment vegetation & Minimal vegetation clearance & Davies (1994) \\
\hline $\begin{array}{l}\text { Macroinvertebrate } \\
\text { community }\end{array}$ & $\begin{array}{l}\text { Water quality class II or better (according to the German saprobic } \\
\text { system) }\end{array}$ & Ehlert et al. (2002) \\
\hline
\end{tabular}

sub-basin (upstream of the site) for all criteria. These 20 criteria include a wide range of human uses and disturbances on streams in our study area, as well as some general aspects on naturalness which must be present if a site to be considered a reference site.

A priori selection and validation of reference sites selected by means of the MRC

Most of the sites included in the GUADALMED project (92 out of 162; 57\%) fulfilled all 20 criteria and were, therefore, considered reference sites in the a priori selection. Of the total sites, $36 \%$ were classified as minor disturbed and only $7 \%$ as disturbed sites (Table 6). On the basis of the number of reference sites, the least disturbed stream type was siliceous headwaters (84\% of all stream type 3 sites were undisturbed), followed by temporary streams (71\% of all stream type 1 sites were undisturbed), calcareous median $(62 \%$ of all stream type 4 sites were undisturbed) and evaporate calcareous (31\% of all stream type 2 sites were undisturbed). Therefore, reference sites were found for all stream types, except for stream type 5 (large watercourses). 
Table 3 Criteria related to physical-chemical features applied for the selection of reference sites in previous studies

\begin{tabular}{|c|c|c|}
\hline $\begin{array}{l}\text { Physical and } \\
\text { chemical criteria }\end{array}$ & Definition & Reference \\
\hline \multirow{17}{*}{$\begin{array}{l}\text { Point sources of } \\
\text { pollution }\end{array}$} & No point-source pollution & Hering et al. (2003), Nijboer et al. (2004) \\
\hline & No point-source eutrophication & Hering et al. (2003), Nijboer et al. (2004) \\
\hline & No intense eutrophication & Ehlert et al. (2002) \\
\hline & Minimal chemical stressors & Hughes (1995) \\
\hline & $\begin{array}{l}\text { Minimal Point-source discharge (sewage treatment plants, light } \\
\text { and heavy industry, and agro-industry) }\end{array}$ & Davies (1994) \\
\hline & Absence of known point sources of nutrient & Hering et al. (2003) \\
\hline & $\begin{array}{l}\text { No known or expected diffuse inputs. Minimum: near to natural } \\
\text { background levels describing the baseload of a specific } \\
\text { catchment area }\end{array}$ & Hering et al. (2003) \\
\hline & $\begin{array}{l}\text { Specific synthetic pollutants: Pressures resulting in } \\
\text { concentrations close to zero or at least below the limits of } \\
\text { detection for the most advanced analytical techniques of } \\
\text { general use }\end{array}$ & Wallin et al. (2003) \\
\hline & Specific non-synthetic pollutants: natural background level/load & Wallin et al. (2003) \\
\hline & $\begin{array}{l}\text { Other effluents/discharges: No or very local discharges with only } \\
\text { very minor ecological effects }\end{array}$ & Wallin et al. (2003) \\
\hline & N-Nitrite concentration $<0.015(\mathrm{mg} / \mathrm{l})$ & Bonada et al. (2004) \\
\hline & Ammonium concentration $<0.5(\mathrm{mg} / \mathrm{l})$ & Bonada et al. (2004) \\
\hline & P-Phosphate concentration $<0.05(\mathrm{mg} / \mathrm{l})$ & Bonada et al. (2004) \\
\hline & No signs of impairment by toxic substances & Ehlert et al. (2002) \\
\hline & Natural colour and odour & Barbour et al. (1996) \\
\hline & Minimal odours, films, scums and slicks & Hughes (1995) \\
\hline & Pipes, drains, ditches and tile absent & Hughes (1995) \\
\hline \multirow{18}{*}{$\begin{array}{l}\text { Diffuse sources of } \\
\text { pollution and land } \\
\text { uses }\end{array}$} & Absence of known or expected diffuse inputs & Hering et al. (2003), Nijboer et al. (2004) \\
\hline & Minimal diffuse source (pesticide runoff ...) & Davies (1994) \\
\hline & Minimal grazing effects & Davies (1994) \\
\hline & Minimal human and living stocks & Hughes (1995) \\
\hline & Minimal catchment urbanisation & Davies (1994), Hering et al. (2003) \\
\hline & Minimal agriculture & Hering et al. (2003) \\
\hline & Minimal intensive agriculture & Davies (1994) \\
\hline & $\begin{array}{l}\text { Pre-intensive agriculture or impacts compatible with pressures } \\
\text { pre-dating any recent land use intensification }\end{array}$ & Wallin et al. (2003) \\
\hline & Minimal silviculture & Hering et al. (2003) \\
\hline & Minimal mining or related industry & Davies (1994) \\
\hline & Minimal forestry impact (percentage of catchment logged) & Davies (1994) \\
\hline & No liming activities & Hering et al. (2003), Nijboer et al. (2004) \\
\hline & $\begin{array}{l}\text { No intensive use of reference sites for recreation purposes (no } \\
\text { intensive camping, swimming, boating, etc. ...) }\end{array}$ & Wallin et al. (2003) \\
\hline & Urban, agricultural and industrial land use $<10 \%$ & Bonada et al. (2004) \\
\hline & No sign of acidification & $\begin{array}{l}\text { Hering et al. (2003), Wallin et al. (2003), } \\
\text { Nijboer et al. (2004) }\end{array}$ \\
\hline & Natural thermal condition & $\begin{array}{l}\text { Ehlert et al. (2002), Hering et al. (2003), } \\
\text { Nijboer et al. (2004) }\end{array}$ \\
\hline & Natural sign of salinity & Hering et al. (2003), Nijboer et al. (2004) \\
\hline & Minimal sedimentation and turbidity & Hughes (1995) \\
\hline
\end{tabular}


Table 4 Criteria related to hydromorphological features applied for the selection of reference sites in previous studies

\begin{tabular}{|c|c|c|}
\hline $\begin{array}{l}\text { Hydromorphological } \\
\text { criteria }\end{array}$ & Definition & Reference \\
\hline \multirow[t]{15}{*}{ River morphology } & Shoreline complex & Hughes (1995) \\
\hline & Channel sinuosity & Hughes (1995) \\
\hline & $\begin{array}{l}\text { Natural channel structures typical of the region (pools, } \\
\text { riffles, runs ...). Macrohabitat structural complexity }\end{array}$ & Hughes (1995), Barbour et al. (1996) \\
\hline & Shoreline modification or degradation minimal & Davies (1994), Hughes (1995) \\
\hline & $\begin{array}{l}\text { No canalisation. Stream bottoms and stream margins must } \\
\text { not be fixed }\end{array}$ & $\begin{array}{l}\text { Hering et al. (2003), Bonada et al. (2004), } \\
\quad \text { Nijboer et al. (2004) }\end{array}$ \\
\hline & Minimal canalisation & Hughes (1995) \\
\hline & No migration barriers & Hering et al. (2003), Nijboer et al. (2004) \\
\hline & Only moderate influence due to flood protection measures & Hering et al. (2003) \\
\hline & No flood protection & Nijboer et al. (2004) \\
\hline & No sediment retention & Nijboer et al. (2004) \\
\hline & Minimal channel and bottom modification & Davies (1994) \\
\hline & Minimal bank degradation & Davies (1994) \\
\hline & Banks representative of undisturbed streams in the region & Hughes (1995), Barbour et al. (1996) \\
\hline & $\begin{array}{l}\text { Artificial instream and bank structures compatible with } \\
\text { ecological functioning equivalent to unmodified }\end{array}$ & Wallin et al. (2003) \\
\hline & $\begin{array}{l}\text { Lateral connectivity compatible with ecological } \\
\text { functioning equivalent to unmodified }\end{array}$ & Wallin et al. (2003) \\
\hline \multirow[t]{3}{*}{ Habitat composition } & $\begin{array}{l}\text { Representative diversity of substrate materials appropriate } \\
\text { to the region or type }\end{array}$ & $\begin{array}{l}\text { Hughes (1995), Barbour et al. (1996), } \\
\text { Ehlert et al. (2002), Bonada et al. } \\
\text { (2004) }\end{array}$ \\
\hline & Presence of woody debris & $\begin{array}{l}\text { Hughes (1995), Hering et al. (2003), } \\
\text { Nijboer et al. (2004) }\end{array}$ \\
\hline & Presence of macrophytes & Hughes (1995) \\
\hline \multirow[t]{10}{*}{$\begin{array}{l}\text { Hydrological conditions } \\
\text { and regulation }\end{array}$} & $\begin{array}{l}\text { Flow modifications minimal (presence of dams, irrigation } \\
\text { canals and field drains) }\end{array}$ & Hughes (1995) \\
\hline & $\begin{array}{l}\text { No alterations of the natural hydrograph and discharge } \\
\text { regime }\end{array}$ & $\begin{array}{l}\text { Barbour et al. (1996), Ehlert et al. (2002), } \\
\text { Hering et al. (2003), Bonada et al. } \\
\text { (2004), Nijboer et al. (2004) }\end{array}$ \\
\hline & No or minor upstream impoundments & Davies (1994), Hering et al. (2003) \\
\hline & $\begin{array}{l}\text { Weirs and reservoirs retaining sediments must not be } \\
\text { present }\end{array}$ & Ehlert et al. (2002), Hering et al. (2003) \\
\hline & No water diversion, abstraction or pulse releases & Hering et al. (2003), Nijboer et al. (2004) \\
\hline & Presence of standing water bodies & Hering et al. (2003), Nijboer et al. (2004) \\
\hline & Minimal extraction or diversion & Davies (1994) \\
\hline & $\begin{array}{l}\text { Levels of regulation resulting in only very minor reductions } \\
\text { in flow levels or lake level changes having no more than } \\
\text { very minor effects on quality elements }\end{array}$ & Wallin et al. (2003) \\
\hline & $\begin{array}{l}\text { Levels of abstraction resulting in only very minor } \\
\text { reductions in flow levels or lake level changes having no } \\
\text { more than very minor effects on the quality elements }\end{array}$ & Wallin et al. (2003) \\
\hline & Minimal floodplain and wetland drainage & Davies (1994) \\
\hline
\end{tabular}

In general, the most limiting criteria were those related to natural land use and to dry land farming, which affected more than $20 \%$ of the sites.
Additionally, disturbances caused by the presence of reservoirs, retention of sediments, exotic species and irrigated farming affected a considerable 
Table 5 Proposed criteria for Mediterranean stream assessment (Mediterranean Reference Criteria, MRC) according to the WFD

\begin{tabular}{|c|c|}
\hline Elements & Criteria \\
\hline Riparian vegetation zone & $\begin{array}{l}\text { 1. Cover and composition appropriate for the type and geographical location of the river } \\
\text { 2. Lateral connectivity between river and riparian corridor is maintained (no cultivation and } \\
\text { significant impervious area in riparian zone) }\end{array}$ \\
\hline Introduced species & 3. No significant impairment by exotic plant or animal species on autochthonous species \\
\hline Point sources of pollution & $\begin{array}{l}\text { 4. No dumping of urban effluents } \\
\text { 5. No dumping of industrial effluents } \\
\text { 6. No irrigation return channel for floodwater farming }\end{array}$ \\
\hline $\begin{array}{l}\text { Diffuse sources of pollution } \\
\text { and land uses }\end{array}$ & $\begin{array}{l}\text { 7. Dry land farming }<20 \% \text { of drainage area (cereal, vineyard and tree crops as olive) and not } \\
\text { connected to riparian vegetation zone } \\
\text { 8. Intensive irrigated farming }<3 \% \text { in drainage area (rice field, irrigated vineyard and others irrigated } \\
\text { fruit tress) and not connected to riparian vegetation zone } \\
\text { 9. Urban use }<0.7 \% \text { in drained area } \\
\text { 10. Burnt vegetation }<7 \% \text { in drainage area at least seven years ago and not connected to riparian } \\
\text { vegetation zone } \\
\text { 11. No evidence of intensive use of grazing } \\
\text { 12. Natural land uses }>80 \% \text { in drainage area }\end{array}$ \\
\hline $\begin{array}{l}\text { River morphology and } \\
\text { habitat conditions }\end{array}$ & $\begin{array}{l}\text { 13. Representative diversity of substrate materials appropriate for the type } \\
\text { 14. No canalisation (stream bottoms and stream margins must not be fixed) } \\
\text { 15. No transversal structures "dams" (no retention of sediments) } \\
\text { 16. No sand or gravel extraction }\end{array}$ \\
\hline $\begin{array}{l}\text { Hydrological conditions } \\
\text { and regulation }\end{array}$ & $\begin{array}{l}\text { 17. No water diversion for irrigation or other purpose } \\
\text { 18. No alterations of the natural hydrograph and discharge regime (reservoirs, hydroelectric...) } \\
\text { 19. No effect of inter-basin water transfer } \\
\text { 20. Near natural level of groundwater (aquifer not affected by over-exploitation) }\end{array}$ \\
\hline
\end{tabular}

Table 6 Number of sites according to the number of Mediterranean Reference Criteria fulfilled for each stream types (T1: stream type 1, T2: stream type 2, T3: stream type 3, T4: stream type 4 and T5: stream type 5)

\begin{tabular}{|c|c|c|c|c|c|c|c|}
\hline \multirow[t]{2}{*}{ Exposure to stressor levels } & \multirow{2}{*}{$\begin{array}{l}\text { Criteria } \\
\text { fulfilled }\end{array}$} & \multicolumn{6}{|c|}{ Stream types } \\
\hline & & $\mathrm{T} 1$ & $\mathrm{~T} 2$ & $\mathrm{~T} 3$ & $\mathrm{~T} 4$ & $\mathrm{~T} 5$ & Total \\
\hline $\begin{array}{l}\text { (1) Undisturbed sites or very minor } \\
\text { disturbed sites }\end{array}$ & 20 & 17 & 10 & 21 & 44 & & 92 \\
\hline \multirow[t]{4}{*}{ (2) Minor disturbed sites } & 19 & 2 & 4 & & 13 & 1 & 20 \\
\hline & 18 & 2 & 4 & 2 & 7 & & 15 \\
\hline & 17 & 3 & 7 & & 2 & & 12 \\
\hline & 16 & & 5 & 1 & 3 & 3 & 12 \\
\hline \multirow[t]{3}{*}{ (3) Disturbed sites } & 15 & & 1 & & 2 & 2 & 5 \\
\hline & 14 & & 1 & & & 2 & 3 \\
\hline & 13 & & & 1 & & 2 & 3 \\
\hline Total & & 24 & 32 & 25 & 71 & 10 & 162 \\
\hline
\end{tabular}

percentage of sites $(10-14 \%)$. Canalisation, adequate substrates and grazing were the criteria which all the sites fulfilled.
In particular, the most limiting criteria for type 1 (temporary streams) were those mostly related to land use and the presence of exotic species (Fig. 2). Land 


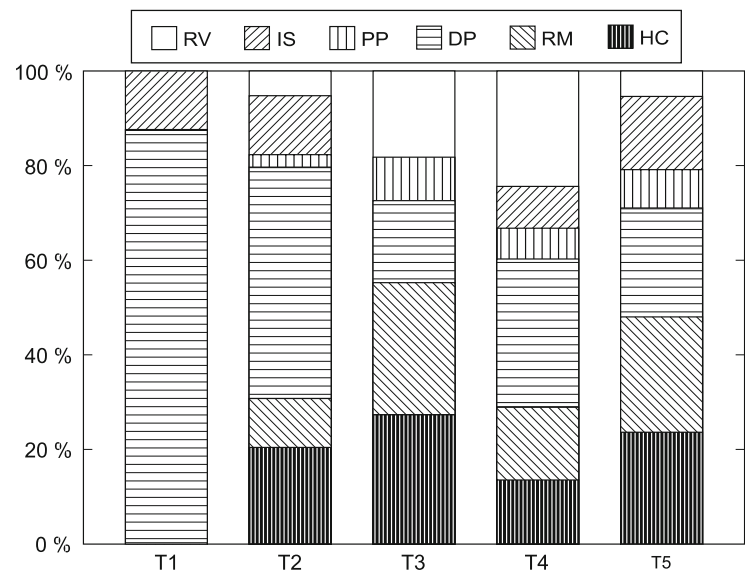

Fig. 2 Percentage of sites which failed criteria for the six categories from the total of non reference sites for each stream type. (RV, Riparian Vegetation zone; IS, Introduced Species; PP, Point sources of Pollution; DP, Diffuse sources of Pollution and land uses; RM, River Morphology and habit conditions and $\mathrm{HC}$, Hydrological Conditions and regulation)

use and hydrologic conditions were the most restraining criteria with the type 2 sites (evaporite calcareous streams at medium altitude). For stream type 3 sites
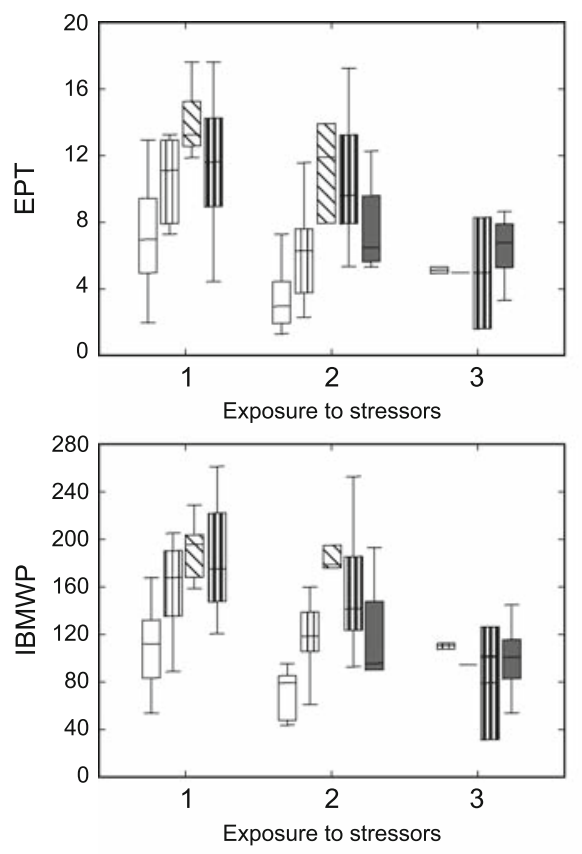

$\square$ T1 $\left.|| l|| l|| l\right|^{\mathrm{T} 2}$

Fig. 3 Multiple box-plots for NFAM, EPT, IBMWP and IASPT values for all five stream types for the levels of exposure to stressors considered. Boxes are interquartile ranges (25th percentile to 75 th percentile) ranges bars show maximum (siliceous headwater streams at high altitude), river morphology and hydrological conditions were the most limiting criteria, while types 4 and 5 were limited by riparian vegetation and land use, and by river morphology and hydrological conditions, respectively.

Reference sites presented higher median values of the four metrics studied than those sites that failed some of the criteria (Fig. 3). In general, as the level of exposure to stressors increased, the median values of macroinvertebrate metrics decreased, with some exceptions. The median and 25th percentile values for number of families, EPT and IBMWP for stream type 2 were lower for exposure to stressors level 2 than for exposure to stressors level 3. Type 3 reference sites (siliceous headwaters) presented the highest median values, followed by types 4,2 and 1 . These values for types 2 and 4 were the most similar, and this pattern was also observed in exposure to stressors level 2, but not for the most disturbed sites, probably because of the scarcity of sites at exposure to stressors level 3 .

The IBMWP $>100$ threshold was used as a validation criterion. All the a priori reference sites
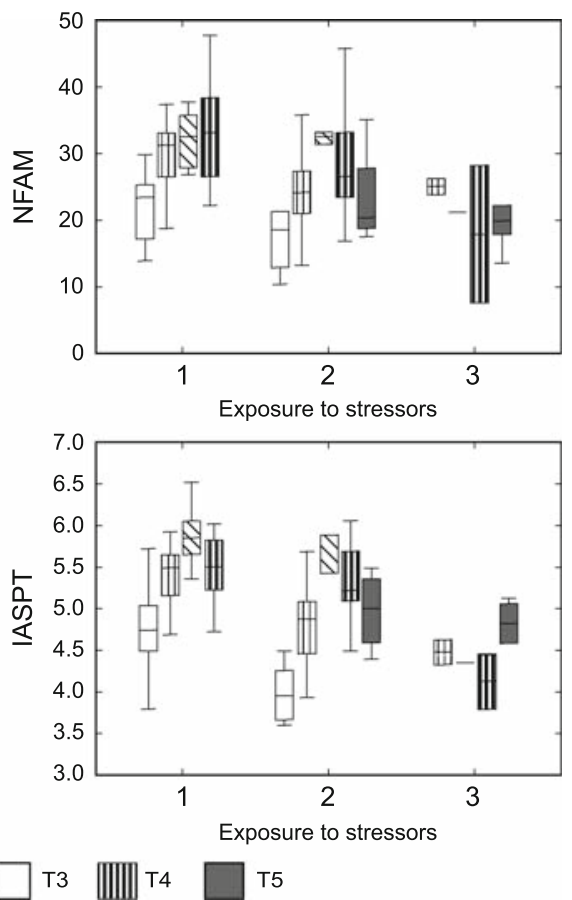

and minimum values and lines represent medians. (T1: stream type 1, T2: stream type 2, T3: stream type 3, T4: stream type 4 and T5: stream type 5) 
exceeded this value on the three sampling occasions. Therefore the 92 a priori reference sites were selected as true reference sites in the final selection. Since all the sites were included in the final selection, consistency was observed between the selection and the validation method, which implies that sites were appropriately selected.

\section{Discussion}

The application of criteria for the recognition and selection of reference sites has been widely reported (e.g. Davies, 1994; Hughes, 1995; Barbour et al., 1996; Reynoldson \& Wright, 2000; Ehlert, 2002; Hering et al., 2003; Wallin et al., 2003; Bonada et al., 2004; Nijboer et al., 2004). A review of the criteria used by the above-mentioned authors showed that, in relation to the number of criteria examined, the most relevant categories are: riparian vegetation, diffuse and point sources of pollution, channel morphology and hydrological conditions and regulations. However other aspects such as introduced species, biomanipulation, presence of wildlife, catchment vegetation, and macroinvertebrate and habitat composition were not considered by many authors.

\section{Mediterranean Reference Criteria}

In this study, six categories were used to establish criteria to select the reference sites in Mediterranean streams (see Table 5). Stoddard et al. (2006) explained that these criteria, which are developed for the purpose of establishing the least amount of human ambient disturbance, vary across ecological regions as the characteristics of the landscape and the human use of the landscape vary. In this sense, we believe that the conventional criteria developed in more temperate areas may not always be applicable or sufficient to identify a reference condition in Mediterranean regions. Hence, the particular features of Mediterranean streams and the most frequent pressures have been taken account to define and apply these criteria and, for that reason, some consideration about these criteria must be emphasised.

Riparian vegetation cover in Mediterranean streams is highly variable, depends on the system type (permanent, ephemeral or intermittent) and reflects the prevailing hydrologic regimen (Salinas et al., 2000). In fact, natural riparian vegetation of some typical ramblas, intermittent or ephemeral streams (Williams, 2006) in Mediterranean regions may be scarce or even absent as a result of water stress and floods (Suárez et al., 2004; Gómez et al., 2005). Therefore, these differences in stream types must be taken account when applying the criterion related to the presence of natural cover and the composition of riparian vegetation.

Regarding to the criterion related to introduced species, the fact that water basins in Spain have been affected for decades by the introduction of exotic species must be considered. These additions produce a biotic homogenisation of freshwater fauna, like the increased similarity of biota over time caused by the replacement of native species with nonindigenous species (Rahel, 2002). This uniformity is of special concern for fish fauna as $38 \%$ of the freshwater species found in Spain are exotic. Native fish fauna is currently threatened by predation and competition with these exotic species (Elvira, 1998; Elvira \& Almodóvar, 2001; Vila-Gispert et al., 2005; Clavero \& García-Berthou, 2006). Moreover in some basins examined in this study, both the red swamp crayfish (Procambarus clarkii) and the red-eared slider (Trachemys scripta) were present. In this context the presence of some exotic fauna produces highly disturbed stream communities regardless of upstream land use activity.

The absence of urban and industrial effluent discharges upstream of potential reference sites must be considered. These effluent discharges upstream of potential reference sites have a greater effect on ephemeral streams than on other types of streams. At very a low flow or no flow, there can be little effluent dilution, which results in high concentrations of contaminants, particularly nutrients.

Mediterranean streams, like other watercourses in semi-arid regions, are particularly susceptible to water diversion (directly or via groundwater withdrawal) and flow regulation (Gasith \& Resh, 1999). The flow fluctuations below reservoirs are highly variable (Petts, 1984; Casado et al., 1989; Bernez et al., 2002) and depend on the inherent properties of the stream, as well as oscillations in the demand of water. As a result, it is difficult to define a minimal downstream distance of recovery (McAllister et al., 2001) of hydrological and geomorphological conditions for the macroinvertebrate community and other 
biological components. As specific studies are lacking the affected stream reaches in the study area that help to define that minimal distance, we considered that a reference site cannot be located downstream of a dam. In addition, a criterion related to inter-basin water transfers, which are common in Mediterranean areas and lead to serious alterations in both the donor and the receptor basins (Castella et al., 1995; Prat \& Ibañez, 1995; Davies et al., 2000; Gibbins et al., 2000), was included, seeing as that sites affected by the flow regulation from this activity cannot be considered as presented in reference conditions.

Specific but very frequent pressures that occur in Mediterranean areas have been considered in this work by the inclusion of novel criteria which, to our knowledge, have not been previously considered. One such case is the criterion related to the effects of wildfire. Effects of fire on stream ecosystems are attributed mainly to physical disturbances associated with increased runoff and sediment scouring, both of which produce long-term changes in abiotic (i.e. abrupt alterations in water chemistry) and biotic properties of lotic ecosystems, such as alterations in the availability of food resources and stream retention capacity (e.g. Minshall et al., 1989; Mishall et al., 1997; Gresswell, 1999). The number of fires occurring in eastern Spain has dramatically increased since the mid 70s, and it is attributed to land use and climate changes (Pausas, 2004). These observations support the inclusion of this criterion when selecting reference sites, because a reference sites cannot be affected by a significant burnt area. The threshold established for the percentage of burnt area has been determined according to studies conducted in Mediterranean areas (Inbar et al., 1998; Mayor et al., 2007).

The presence of sand and gravel extraction activities is also a novel criterion. These activities, together with the presence of dams, are the main causes of sediment deficiency and the altered granulometric balance noted in many rivers of Spain (Batalla, 2003). Therefore, we believe that the sites affected by these activities cannot present reference conditions.

Drainage channels from traditional agricultural floodwater systems are a typical and frequent pressure in Mediterranean streams (Hooke \& Mant, 2002). These channels may increase nutrient and pesticide concentrations in streams because they return the water use to irrigate agricultural land to streams. Hence, a criterion to avoid the presence of these drainage channels upstream of a site was included.

Finally, we believe that the quantitative state of groundwater must be included as an indicator of ecosystem health. Groundwater use is especially intense and important in Mediterranean areas, where human uses of water often compromise the natural function of stream ecosystems (Gasith \& Resh, 1999). Therefore we consider that near natural groundwater level is an essential criterion to take account of in Mediterranean streams.

\section{A priori selection of reference sites}

Of the 162 sites studied as potential reference sites, 92 were identified as a priori reference sites by applying of the Mediterranean reference criteria, which showed that approximately half of these potential reference sites had no pressures and, consequently, presented natural conditions. Although many sites were influenced by multiple stressors, reference sites were found for all stream types except for large watercourses at medium and low altitude (stream type 5). This stream type included sites allocated at a lower altitude that the rest of stream types in the main axes of rivers and consequently the presence of multiple stressors, that are more common in lowlands, made the selection of undisturbed sites impossible. This problem has been described by other authors in European streams (e.g. Ehlert et al., 2002; Hering et al., 2003; Nijboer et al., 2004; Lorenz et al., 2004; Dodkins et al., 2005), particularly in Mediterranean streams (e.g. Prat \& Munné, 2000; Bonada et al., 2004). The analysis of the pressures identified in each stream type in this study shows that one of the most limiting criteria to find reference sites in all the stream type was the presence of a significant percentage of dry land use, except for the siliceous headwater streams which include sites allocated in the highest regions of the study area (see Table 1). This finding was expected because traditionally the agriculture has been a very important productive sector in the Mediterranean Europe (Allen, 2001), where dry and irrigated farm lands are significantly higher than in other European countries (MIMAN, 2000). Another important pressure presented in all the stream types was the alteration of the natural 
hydrological conditions caused by the presence of reservoirs, except in temporary streams due the low mean annual discharges that characterise this type of streams. This is in the agreement with the knowledge that Mediterranean basins in European countries have a high level of flow regulation given the presence of reservoirs whose storage capacity represents approximately two-thirds of the total capacity of European countries (MIMAM, 2000).

In situations where undisturbed sites are not available to generate a database of reference sites, as is the case of large watercourse at medium and low altitude stream in this study, the use of historical data has been suggested as an additional method to describe reference communities (Ehlert et al., 2002; Nijboer et al., 2004). However, this approach is impossible to apply in this study area because in Spain, as well as in other Mediterranean countries, data of biotic communities covering large catchment areas are recent (e.g. Pinto et al., 2004; Chaves et al., 2006). In a similar context, it has been suggested that those sites which have received less intense impacts fulfilling most of the reference criteria, or meet them closely, might be justifiably used to establish the RC (e.g. Davies, 1994; Hering et al., 2003; Bailey et al., 2004). In this sense, we believe that minor disturbed sites (sites at level 2 which fulfilled more than 15 of the 20 criteria) belonging to large watercourses (stream type 5), where it is not possible to find undisturbed sites, could be considered suitable to establish RC in the sense of the Beast Attainable Condition (BAC) as defined by Stoddard et al. (2006). This term indicates that sites are located in areas where the impact of inevitable land use on biota is minimised. In conclusion, this permissiveness regarding the presence of some pressures in reference sites allows environmental and management goals in order to apply the WFD since other aforementioned approaches are not possible in this specific stream type.

We hypothesised that the values of the macroinvertebrate metrics and indices studied for each typespecific reference site would be higher than those from disturbed sites. This hypothesis was confirmed because undisturbed sites for all the stream types presented higher medians than disturbed sites at different exposure of stressors levels, proving that the analysis of macroinvertebrate communities independently confirm the a priori site selection. This result demonstrates that the criteria proposed for Mediterranean streams in this study reflect a true gradient of disturbance where the values of metrics and indices decreased as site fulfilled lower number of criteria.

Validation of reference sites

Identifying the $\mathrm{RC}$ in areas that are strongly affected by human activities is difficult because of the occurrence of natural and human generated stress and the interaction between stressor-type and the capacity of individual ecosystems (or types of systems) to resist or to recover from disturbances. In this situation, site validation is the next key step to confirm and refine the previous selection of reference sites (Barbour et al., 1996); regardless of the method used to establish the RC, this process must be applied preferably using independent approaches (Nijboer et al., 2004). In this study the macroinvertebrate community was used for validation purposes by applying the reliable biological threshold defined by Alba-Tercedor \& Sánchez-Ortega (1988) and using high quality class indicators in Mediterranean streams (e.g. Chaves et al., 2006).

Although the structure of the macroinvertebrate community should be not used for the a priori selection of reference sites (e.g. Barbour et al., 1996; Bailey et al., 2004), to avoid preconceived ideas about the composition or diversity of the community in typical sites, this community has been recommended to corroborate the $\mathrm{RC}$ and, therefore, the high ecological status in the WFD context (e.g. Wallin et al., 2003; Bailey et al., 2004; Nijboer et al., 2004; Chaves et al., 2006). The use of macroinvertebrate communities as a validation criterion is justified since the knowledge that they reflect the influence of all the stressors on its environment (Karr, 1999; Karr \& Chu, 2000), and are capable of detecting the presence of certain types of disturbances that are difficult to recognise with the common screening methods used. In this study the validation process let to a $100 \%$ confirmation of the a priori reference sites, showing that the applying criteria proposed acts as an appropriate tool to select references sites in Mediterranean streams.

The validation of temporary stream by applying the biological threshold was not possible given the knowledge that macroinvertebrate community in reference sites included in this stream type differs 
greatly from the rest of permanent stream types (Sánchez-Montoya et al., 2007). It must be also emphasised that temporary streams in the study area includes diverse macroinvertebrate communities, and that a further division into subtypes has been suggested because of the large variability in salinity and hydrology conditions (Sánchez-Montoya et al., 2007). Thus, the application of only one value of the IBMWP threshold to identify the RC in temporary stream is not likely to be suitable to ensure a proper validation of this stream type.

The aforementioned large differences in the reference macroinvertebrate communities between temporary streams and the rest of permanent stream types have been confirmed in this study since the values of the studied metrics in reference sites for this stream type are lower than in the rest of seasonal permanent stream types (see Fig. 3). The temporary stream type in the study area includes natural intermittent or ephemeral sites which underwent intense drought periods, and which lead to a predominance of pool habitats frequently disconnected from riffles. The degree of habitat connectivity may influence assemblage richness and diversity. Low taxa richness should be expected in disconnected habitat (Bonada et al., 2006) because low connectivity produces low richness given the exchanges of matter, energy and organism that are constrained between parches (Ward et al., 1999). Based on the knowledge that $\mathrm{OCH}$ families taxa are predominant in pools, because disconnected pools could be a refuge from desiccation for some tolerant lentic macroinvertebrates (i.e. $\mathrm{OCH}$ ) but probably not for rheophilic macroinvertebrates (i.e. EPT) (e.g. Brown \& Brussock, 1991), lower values of both taxa richness (family level) and EPT richness (relative to $\mathrm{OCH}$ richness) in temporary streams is expected (Bonada et al., 2006; Sánchez-Montoya et al., 2007). Besides, the lower IBMWP values in temporary streams in the RC is also accounted by the score of EPT families in the IBMWP (mean value = 8.4) which is significantly higher than in $\mathrm{OCH}$ families (mean $=4.9)$. Additionally, spatial heterogeneity increases from ephemeral to intermittent and to permanent sites because higher flows result in an increase of available refuges and substrate diversity (Bonada et al., 2007) and higher richness taxa is expected with increases of this heterogeneity. In conclusion, lower metric values in the RC in temporary streams, if compared to permanent streams, must be attributed to natural differences in macroinvertebrate communities.

The 25th percentile values of the IBMWP for the distribution of reference sites selected in this study for each stream type are higher than those obtained previously by Alba-Tercedor et al. (2004) in similar stream types. This finding corroborates that the methodology to recognise and select reference sites proposed in this study is an appropriate method to identify undisturbed sites in Mediterranean streams.

Acknowledgements This research was supported by the GUADALMED-2 project (REN2001-3438-C07-01) and by pre-doctoral grants to M.M. Sánchez-Montoya, T. Puntí and J.M. Poquet from the Spanish Ministry of Science and Technology. We would like to thank R. C. Bailey and two anonymous reviewers for their comments that greatly contributed to the improvement of this paper.

\section{References}

Alba-Tercedor, J. \& A. Sánchez-Ortega, 1988. Un método rápido y simple para evaluar la calidad biológica de las aguas continentales basado en el de Hellawell (1978). Limnética 4: 51-56.

Alba-Tercedor, J., P. Jáimez-Cuellar, M. Álvarez, J. Avilés, N. Bonada, J. Casas, A. Mellado, M. Ortega, I. Pardo, N. Prat, M. Rieradevall, S. Robles, C. E. Sáinz-Cantero, A. Sánchez-Ortega, M. L. Suárez, M. Toro, M. R. VidalAbarca, S. Vivas \& C. Zamora-Muñoz, 2004. Caracterización del estado ecológico de ríos mediterráneos ibéricos mediante el índice IBMWP (antes $\mathrm{BMWP}^{\prime}$ ). Limnética 21(2002): 175-186.

Allen, H. D., 2001. Mediterranean ecogeography. Harlow Pearson Education, England.

Bailey, R. C., M. G. Kennedy, M. Z. Dervish \& R. M. Taylor, 1998. Biological assessment of freshwater ecosystems using a reference condition approach: comparing predicted and actual benthic invertebrate communities in Yukon streams. Freshwater Biology 39: 765-774.

Bailey, R. C., H. Norris \& B. Reynoldson, 2004. Bioassessment of Freshwater Ecosystems. Using the Reference Condition Approach. Kluwer Academic Publishers, Dordrecht.

Barbour, M. T., B. D. Gerritsen, B. D. Snyder \& J. B. Stribling, 1999. Rapid Bioassessment Protocols for Use in Streams and Wadeable Rivers. EPA/841/B-99/002. US Enviromental Protection Agency, Washington, DC.

Barbour, M. T., J. B. Stribling \& B. D. Gerritsen, 1996. Biological Criteria: Technical Guidance for Streams and Small Rivers. EPA/822/B-96/001. US. Environmental Protection Agency, Washington, DC.

Batalla, R. J., 2003. Sediment deficit in rivers caused by dams and instream gravel mining. A review with examples from NE Spain. Cuaternario y Geomorfología 17: 79-91. 
Bernez, I., J. Haury \& M. T. Ferreira, 2002. Downstream effects of a hydroelectric reservoir on aquatic plant assemblages. The Scientific World Journal 2: 740-750.

Bonada, N., N. Prat, A. Munné, M. Rieradevall, J. AlbaTercedor, M. Álvarez, J. Avilés, J. Casas, P. JaímezCuéllar, A. Mellado, G. Moyá, I. Pardo, S. Robles, G. Ramón, M. L. Suárez, M. Toro, M. R. Vidal-Abarca, S. Vivas \& C. Zamora-Muñoz, 2004. Criterios para la selección de condiciones de referencia en los ríos mediterráneos. Resultados del proyecto GUADALMED. Limnética 21(2002): 99-114.

Bonada, N., M. Rieradevall, N. Prat \& V. H. Resh, 2006. Benthic macroinvertebrate assemblages and macrohabitat connectivity in Mediterranean-climate streams of northern California. Journal of the North American Benthological Society 25: 32-43.

Bonada, N., M. Rieradevall \& N. Prat, 2007. Macroinvertebrate community structure and biological traits related to flow permanence in a Mediterranean river network. Hydrobiologia 589: 91-106.

Brown, A. V. \& P. P. Brussock, 1991. Comparisons of benthic macroinvertebrates between riffles and pools. Hydrobiologia 220: 99-108.

Casado, C., D. de Jalón García, C. Montes, E. Barceló \& F. Menes, 1989. The effect of an irrigation and hydroelectric reservoir on its downstream communities. Regulated Rivers: Research and Management 4: 275-284.

Castella, E., M. Bickerton, P. D. Armitage \& G. E. Petts, 1995. The effects of water abstractions on invertebrate communities in U.K. streams. Hydrobiologia 308: 167-182.

Centro Geográfico del Ejército, 2005. Digital Terrain Model. Ministerio de Defensa, Spain.

Chaves, M. L., J. L. Costa, P. Chainho, M. J. Costa \& N. Prat, 2006. Selection and validation of reference sites in small river basins. Hydrobiologia 573: 133-154.

Chovarec, A., P. Jäger, M. Jungwirth, V. Koller-Kreimel, O. Moog, S. Muhar \& S. Schmutz, 2000. The Austrian way of assessing the ecological integrity of running waters: a contribution to the EU Water Framework Directive. Hydrobiologia 422(423): 445-452.

Clavero, M. \& E. García-Berthou, 2006. Homogenization dynamics and introduction routes of invasive freshwater fish in the Iberian Peninsula. Ecological Applications 16: 2313-2324.

Davies, P. E., 1994. Monitoring river health initiative. River bioassessment manual. National River Process and Management Program. Freshwater system, Tasmania.

Davies, B. R., C. D. Snaddon, M. J. Wishart, M. Thoms \& M. Meador, 2000. A biogeographical approach to interbasin water transfers: implications for river conservation. In Boon, P. J., B. R. Davies \& G. E. Petts (eds), Global Perspectives of River Conservation: Science, Policy and Practice. Wiley, Chichester, UK: 431-444.

Dodkins, I., B. Rippey, T. J. Harrington, C. Bradley, B. N. Chathain, M. Kelly-Quinn, M. McGarrigle, S. Hodge \& D. Trigg, 2005. Developing an optimal river typology for biological elements within the Water Framework Directive. Water Research 39: 3479-3486.

Elvira, B., 1998. Impact of introduced fish on the native freshwater fish fauna of Spain. In Cows, I. G. (ed.),
Stocking and Introduction on fish. Fishing News Books. Blackwell Science Ltd, USA: 186-190.

Elvira, B. \& A. Almodóvar, 2001. Freshwater fish introductions in Spain: facts and figures at the beginning of the 21st century. Journal of Fish Biology 59: 323-331.

Ehlert, T., D. Hering, U. Koenzen, T. Pottgiesser, H. Schuhmacher \& G. Friedrich, 2002. Typology and type specific reference conditions for medium-sized and large rivers in North Rhine-Westphalia: methodical and biological aspects. International Review of Hydrobiology 87: 151-163.

European Commission, 2000. Directive 2000/60/EC of the European parliament of the council of 23 October 2000 establishing a framework for Community action in the field of water policy. Official Journal of the European Communities L327: 1-72.

Gasith, A. \& V. H. Resh, 1999. Streams in Mediterranean climate region: abiotic influences and biotic responses to predictable seasonal events. Annual Review of Ecology and Systematic 30: 51-81.

Gibbins, C. N., M. J. Jeffries \& C. Soulsby, 2000. Impacts of an inter-basin water transfer: distribution and abundance of Micronecta poweri (Insecta: Corixidae) in the River Wear, north-east England. Aquatic Conservation: Marine and Freshwater Ecosystems 10: 103-115.

Gómez, R., I. Hurtado, M. L. Suárez \& M. R. Vidal-Abarca, 2005. Ramblas in south-east Spain: threatened and valuable ecosystems. Aquatic Conservation: Marine and Freshwater Ecosystems 15: 387-402.

Gresswell, R. E., 1999. Fire and aquatic ecosystems in forested biomes of North America. Transactions of the American Fisheries Society 28: 193-221.

Hering, D., A. Buffagni, O. Moog, L. Sandin, M. Sommerhaüser, I. Stubauer, C. Feld, R. Johnson, P. Pinto, N. Skoulikidis, P. Verdonschot \& S. Zahrádková, 2003. The development of a system to assess the ecological quality of streams based on macroinvertebrates-design of the sampling programme within the AQEM project. International Review of Hydrobiology 88: 345-361.

Hooke, J. M. \& J. Mant, 2002. Floodwater use and management strategies in valleys of southest Spain. Land degradation \& Development 13: 165-175.

Hughes, R. M., 1995. Defining acceptable biological status by comparing with reference conditions. In Davies, W. S. \& T. P. Simon (eds), Biological Assessment and Criteria. Tools for Water Resource Planning and Decision Making. Lewis Publishers, Boca Raton, FL: 31-47.

Inbar, M., M. Tamir \& L. Wittenberg, 1998. Runoff and erosion processes after a forest fire in Mount Carmel, a Mediterranean area. Geomorphology 24: 17-33.

Jáimez-Cuéllar, P., S. Vivas, N. Bonada, S. Robles, A. Mellado, M. Álvarez, J. Avilés, J. Casas, M. Ortega, I. Pardo, N. Prat, M. Rieradevall, C. E. Sáinz-Cantero, A. Sánchez-Ortega, M. L. Suárez, M. Toro, M. R. Vidal-Abarca, C. ZamoraMuñoz \& J. Alba-Tercedor, 2004. Protocolo Guadalmed (PRECE). Limnética 21(2002): 187-204.

Karr, J. R., 1999. Defining and measuring river health. Freshwater Biology 41: 221-234.

Karr, J. R. \& E. W. Chu, 2000. Sustaining living rivers. Hydrobiologia 422: 1-14.

Köppen, W., 1923. De Klimate der Erde. Borntrager, Berlin. 
Lorenz, A., K. C. Feld \& D. Hering, 2004. Typology of streams in Germany based on benthic invertebrates: ecoregions, zonation, geology and substrate. Limnologica 34: 379-389.

Mayor, A. G., S. Bautista, J. Llovet \& J. Bellot, 2007. Post-fire hydrological and erosional responses of a Mediterranean landscape: seven years of catchment-scale dynamics. Catena 71: 68-75.

McAllister, D. E., J. F. Craig, N. Davisdon, S. Delany \& M. Seddon, 2001. Biodiversity impacts of large dams. UNEP, United Nations Foundation and IUCN The World Conservation Union.

MIMAN, 2000. Las aguas continentales en los países mediterráneos de la Unión Europea. Ministerio de Medio Ambiente de España, CEDEX.

Minshall, G. W., J. T. Brock \& J. D. Varley, 1989. Wildfires and Yellowstone's stream ecosystems: a temporal perspective shows that aquatic recovery parallels forest succession. BioScience 39: 707-715.

Minshall, G. W., C. T. Robinson \& D. E. Lawrence, 1997. Postfire responses of lotic ecosystems in Yellowstone National Park. U.S.A. Canadian Journal of Fisheries and Aquatic Sciences 54: 2509-2525.

Nijboer, R. C., R. K. Jhonson, P. F. M. Verdonschot, M. Sommerhaüser \& A. Buffagni, 2004. Establishing reference conditions for European streams. Hydrobiologia 516: 91-105.

Norris, R. H. \& M. C. Thoms, 1999. What is river health? Freshwater Biology 41: 197-209.

Pausas, J. G., 2004. Changes in fire and climate in the eastern Iberian Peninsula (Mediterranean Basin). Climate Change 63: 337-350.

Petts, G. E., 1984. Impounded Rivers: Perspectives for Ecological Management. John Wiley and Sons Ltd., UK.

Petts, G. E., 1989. Historical Change of Large Alluvial Rivers: Western Europe. Wiley, Chichester.

Pinto, P., J. Rosado, M. Morais \& I. Antunes, 2004. Asessment methodology for southern siliceous basins in Portugal. Hydrobiologia 516: 191-214.

Prat, N., 2004. El proyecto GUADALMED sobre el Estado Ecológico de los ríos Mediterráneos. Limnética 21(2002): $1-3$.

Prat, N. \& C. Ibañez, 1995. Effects of water transfers projected in the Spanish National Hydrological Plan on the ecology of the lower river Ebro (N.E. Spain) and its delta. Water Science Technology 31: 79-86.

Prat, N. \& A. Munné, 2000. Water use and quality and stream flow in a Mediterraneam stream. Water Research 34: 3876-3881.

Rahel, F. J., 2002. Homogenization in freshwater. Annual Review of Ecology and Systematics 33: 291-315.

Reynoldson, T. B., R. H. Norris, V. H. Resh, R. H. Day \& D. M. Rosenberg, 1997. The reference condition: a comparison of multimetric and multivariate approaches to assess water-quality impairment using benthic macro invertebrates. Journal of the North American Benthological Society 16: 833-852.

Reynoldson, T. B. \& J. F. Wright, 2000. The reference condition: problems and solutions. In Wright, J. F., D. W. Sutcliffe \& M. T. Furse MT (eds), Assessing the biological quality of fresh waters: RIVPACS and others techniques. Freshwater Biological Association, Ambleside, Cumbia, UK: 293-303.

Salinas, M. J., G. Blanca \& A. T. Romero, 2000. Evaluating riparian vegetation in semi-arid Mediterranean watercourses in the south-eastern Iberian Peninsula. Environmental Conservation 27: 24-35.

Sánchez-Montoya, M. M., M. L. Suárez \& M. R. Vidal-Abarca, 2005. Propuesta de criterios para la selección de estaciones de referencia en ríos mediterráneos en el contexto de la DMA. Technología del Agua 167: 42-52.

Sánchez-Montoya, M. M., T. Puntí, M. L. Suárez, M. R. VidalAbarca, M. Rieradevall, J. M. Poquet, C. Zamora-Muñoz, S. Robles, M. Álvarez, J. Alba-Tercedor, M. Toro, A. Pujante, A. Munné \& N. Prat, 2007. Concordance between ecotypes and macroinvertebrate assemblages in Mediterranean streams. Freshwater Biology 52: 22402255.

Stoddard, J. L., D. P. Larse, C. P. Hawkins, R. K. Jonson \& R. H. Norris, 2006. Setting expectations for the ecological conditions of streams: the concept of reference condition. Ecological Applications 16: 1267-1276.

Suárez, M. L., M. R. Vidal-Abarca, M. M. Sánchez-Montoya, J. Alba-Tercedor, M. Álvarez, J. Avilés, N. Bonada, J. Casas, P. Jáimez-Cuéllar, A. Munné, I. Pardo, N. Prat, M. Rieradevall, M. J. Salinas, M. Toro \& S. Vivas, 2004. Las riberas de los ríos mediterráneos y su calidad: el uso del índice QBR. Limnética 21(2002): 135-148.

Vila-Gispert, A., C. Alcaraz \& E. García-Berthou, 2005. Lifehistory traits fish in small Mediterranean streams. Biological Invasions 7: 107-116.

Wallin, M., T. Wiederholm \& R. K. Johnson, 2003. Guidance on establishing reference conditions and ecological status class boundaries for inland surface waters. Final Report to the European Commission from CIS Working Group 2.3 REFCOND.

Ward, J. V., K. Tockner \& F. Schiemer, 1999. Biodiversity of floodplain river ecosystems: ecotones and connectivity. Regulated Rivers: Research and Management 15: 125-139.

Williams, D. D., 2006. The Biology of Temporary Waters. Oxford University Press, New York.

Zamora-Muñoz, C. \& J. Alba-Tercedor, 1996. Bioassessment of organically polluted Spanish rivers, using a biotic index and multivariate methods. Journal of the North American Benthological Society 15: 332-352. 